\title{
Hepatitis B virus subgenotype C2- and B2-associated mutation patterns may be responsible for liver cirrhosis and hepatocellular carcinoma, respectively
}

\author{
Y.M. Chen, S.H. Wu, C.N. Qiu, D.J. Yu and X.J. Wang \\ Department of Laboratory Medicine, Affiliated Hangzhou Hospital, Nanjing Medical University, Hangzhou, China
}

\begin{abstract}
The objective of this study was to examine hepatitis B virus (HBV) subgenotypes and mutations in enhancer II, basal core promoter, and precore regions of HBV in relation to risks of liver cirrhosis (LC) and hepatocellular carcinoma (HCC) in Southeast China. A case-control study was performed, including chronic hepatitis B (CHB; $n=125), L C(n=120)$, and HCC $(n=136)$. HBV was genotyped by multiplex polymerase chain reaction and subgenotyped by restriction fragment length polymorphism. HBV mutations were measured by DNA sequencing. HBV genotype C (68.2\%) predominated and genotype B (30.2\%) was the second most common. Of these, C2 (67.5\%) was the most prevalent subgenotype, and B2 (30.2\%) ranked second. Thirteen mutations with a frequency $>5 \%$ were detected. Seven mutation patterns (C1653T, G1719T, G1730C, T1753C, A1762T, G1764A, and G1799C) were associated with C2, and four patterns (C1810T, A1846T, G1862T, and G1896A) were associated with B2. Six patterns (C1653T, G1730C, T1753C, A1762T, G1764A, and G1799C) were obviously associated with LC, and 10 patterns (C1653T, G1730C, T1753C, A1762T, G1764A, G1799C, C1810T, A1846T, G1862T, and G1896A) were significantly associated with HCC compared with CHB. Four patterns (C1810T, A1846T, G1862T, and G1896A) were significantly associated with HCC compared with LC. Multivariate regression analyses showed that HBV subgenotype C2 and C2-associated mutation patterns (C1653T, T1753C, A1762T, and G1764A) were independent risk factors for LC when CHB was the control, and that B2-associated mutation patterns (C1810T, A1846T, G1862T, and G1896A) were independent risk factors for HCC when LC was the control.
\end{abstract}

Key words: Hepatitis B virus; Genotype; Core promoter; Precore; Mutation; Advanced liver disease

\section{Introduction}

More than 350 million people are chronically infected with hepatitis B virus (HBV) worldwide. Asia and Africa are high endemic areas. It is estimated that approximately 15 to $40 \%$ of patients with chronic infection will eventually progress to liver cirrhosis (LC), liver failure, and hepatocellular carcinoma (HCC) (1). Chronic HBV infection is a major cause of LC and HCC, but the pathogenesis remains elusive. In addition to the consumption of poisons and host determinants, the virological characteristics of HBV should be widely studied.

HBV has been classified into eight well-characterized genotypes $(\mathrm{A}$ to $\mathrm{H})$ based on a sequence divergence of greater than $8 \%$ over the entire HBV genome, which reflect distinctive geographical distributions (2). Genotype A is prevalent in Northwestern Europe, sub-Saharan Africa, North America, and India. Genotypes B and C are predominant in Asia. Genotype D has a worldwide prevalence, but it is the most common genotype in the Mediterranean region. Genotype $\mathrm{E}$ is mainly restricted to Western Africa, and genotypes $\mathrm{F}$ and $\mathrm{H}$ have been found in South and Central America, respectively. Finally, genotype $G$ has been identified in Europe as well as in North and Central America $(3,4)$. Genotypes are further categorized into subgenotypes based on nucleotide sequence divergence between 4 and $8 \%$. For example, genotype B is divided into subgenotypes $\mathrm{B} 1$ to $\mathrm{B} 6$, and genotype $\mathrm{C}$ includes the subgenotypes $\mathrm{C} 1$ to $\mathrm{C} 5$. Both the $\mathrm{B}$ and $\mathrm{C}$ subgenotypes are mainly prevalent in East and Southeast Asia (5). Importantly, some studies indicated that the HBV genotype/subgenotype could influence the progression of liver disease, hepatitis $\mathrm{B}$ e-antigen $(\mathrm{HBeAg})$ seroconversion, and response to antiviral therapy (6-8).

Correspondence: X.J. Wang, Department of Laboratory Medicine, Affiliated Hangzhou Hospital, Nanjing Medical University, No. 261 Huansha Road, Hangzhou 310006, China. Fax: +086-571-8791-4773. E-mail: hzsylab@163.com 
HBV contains four genes with partially overlapping open reading frames encoding the viral surface, precore/ core, polymerase, and $\mathrm{X}$. The enhancer II (enhll; nucleotides 1685-1773) and basal core promoter (BCP; nucleotides 1742-1849) are located within the core promoter (CP) region (nucleotides 1643-1849), which overlaps the X gene (nucleotides 1374-1836) (9). The CP region is thought to play an important role in viral replication. The precore region (nucleotides 1814-1900) encodes HBeAg (10), which is used clinically as an indicator of active viral replication. HBV generates mutation rates more than 10 -fold higher than those of other DNA viruses because its polymerase lacks a proofreading function (11). Multiple mutations have been identified in the enhll/BCP/precore regions, of which the BCP mutations (A1762T/G1764A) and the precore stop codon mutation (G1896A) have been extensively studied. The A1762T/G1764A mutations are associated with severe liver disease, including liver failure, LC, and $\mathrm{HCC}$, and are considered potential biomarkers for HCC $(12,13)$. The G1896A mutation correlates with increased risk of HCC in a newly updated meta-analysis (14). In addition, study of C1653T, T1753V, G1899A, and other mutations in the enhll/BCP/precore regions has just begun (14).

Many cross-sectional and case-control studies have suggested that HBV genotype/subgenotype and enhll/ $\mathrm{BCP} /$ precore mutations have a significant impact on the progression of chronic hepatitis $\mathrm{B}$ ( $\mathrm{CHB})(6,7,12-18)$, but there are also contradictory observations $(9,10,19-22)$. Meanwhile, data are limited on the relationship between HBV subgenotypes, the mutation hot spots in the enhll/ $\mathrm{BCP} /$ precore, and clinicopathological characteristics in chronically infected patients. In this regard, an accurate estimation of the prevalence and distribution of HBV subgenotypes in Southeast China was urgently needed because of the high incidence rates of LC and HCC in this region. In this study, our objective was to elucidate the clinical and virological differences between HBV subgenotypes, as well as the associated risk factors for the progression of chronic HBV infection.

\section{Material and Methods}

\section{Patients}

This study was approved by the Medical Ethics Committee of the Affiliated Hangzhou Hospital, Nanjing Medical University, Hangzhou, China, and all participants completed an informed consent process. A total of 381 patients who visited the Affiliated Hangzhou Hospital of Nanjing Medical University from June 2010 to December 2012 were enrolled. All patients came from Southeast China, including the Provinces of Zhejiang, Jiangsu, and Fujian. All participants were positive for hepatitis B surface antigen ( $\mathrm{HBsAg}$ ) and were divided into three age- and gender-matched groups ( $\mathrm{CHB}, \mathrm{LC}$, and $\mathrm{HCC}$ ).
One hundred and twenty-five $\mathrm{CHB}$ patients (98 males and 27 females, mean age $48.8 \pm 11.9$ years, range 32-67 years) met the diagnostic criteria based on the guidelines of prevention and treatment for CHB (2010 version) of the Chinese Society of Hepatology and Chinese Society of Infectious Diseases, Chinese Medical Association. All were without LC and HCC as detected by liver ultrasound. All $\mathrm{CHB}$ patients agreed to a liver biopsy for increased accuracy of estimating liver tissue damage by Scheuer's classification (23). One hundred and twenty LC patients (86 males and 34 females, mean age $49.1 \pm 10.2$ years, range 33-65 years) were diagnosed by liver ultrasound, computed tomography (CT), and magnetic resonance imaging (MRI). All had accompanying portal hypertension and hypersplenism. One hundred and thirty-six HCC patients (101 males and 35 females, mean age $49.3 \pm 10.3$ years, range $32-71$ years) who met the diagnostic criteria for HCC confirmed by histopathological examination were examined by liver ultrasound, CT, MRI, and serum $\alpha$-fetoprotein (AFP) levels. There were no significant differences among the three groups with respect to gender and age. In addition, none of the participants received anti-viral treatment. Patients presenting other liver diseases, such as autoimmune hepatitis, alcoholic hepatitis, Wilson disease, and other types of hepatitis virus infection, were excluded from this study. Two milliliters of serum was collected from each patient and stored at $-70^{\circ} \mathrm{C}$ until use.

\section{Serological markers and quantitation of HBV DNA}

Serum alanine aminotransferase (ALT), albumin, and total bilirubin (TBIL) were measured by standard procedures. HBV DNA levels were determined using a real-time polymerase chain reaction (PCR) kit (DaAn Gene Diagnostic Co., China) with a lower limit of detection of 500 copies/mL. HBeAg was detected by enzyme-linked immunosorbent assay kits (Kehua Bio-engineering Co., China). Serum hyaluronic acid (HA) and AFP levels were measured by a chemiluminescent assay (Bayer Co., Germany).

\section{Determination of HBV genotypes/subgenotypes and enhIl/BCP/precore mutations}

HBV DNA was extracted using a commercial viral genomic extraction kit (Sunbiotech Co., China). HBV was genotyped by multiplex PCR and subgenotyped by PCR and restriction fragment length polymorphism (RFLP) as described previously $(24,25)$. In addition, 26 serum samples, including 10 with B2 subgenotype, 10 with C2 subgenotype, and 6 with B/C mixed genotypes based on multiplex PCR and RFLP, were identified by sequencing according to Liu et al. (26).

To assess the mutations in the enhll/BCP/precore, sequencing of amplified DNA by nested PCR was carried out following the method of Yin et al. (27). PCR products were directly sequenced by the dideoxy chain termination 
method using Big Dye Terminator in an ABI 3730xI DNA analyzer (Applied Biosystems, USA). The sequences were aligned by ClustalW, an online program used for multiple sequence alignment (http://www.genome.jp/ tools/clustalw/).

After alignment, the nucleotide with the highest frequency at each site in the enhll/BCP/precore regions from the asymptomatic $\mathrm{HBsAg}$ carrier (ASC) state was defined as the wild-type nucleotide. Substitutions with other nucleotides at each site were defined as mutations. The HBV mutation data for ASCs were organized as in Yin et al. (27).

\section{Statistical analysis}

The chi-square test or the Fisher exact test was used to distinguish the differences of frequency distribution in the groups. Statistical significance between two groups with normal distributions was detected by the Student $t$-test, and non-normal distributed data were analyzed using the Mann-Whitney U-test. Associations are reported as odds ratios or as risk estimates with $95 \%$ confidence intervals. Independent risk factors were analyzed by multiple logistic regressions. All statistical tests were two-sided, and a probability of $\mathrm{P}<0.05$ was considered to be statistically significant. Data analysis was performed using the SPSS 11.0 software (SPSS Inc., USA).

\section{Results}

The results of 26 samples showed perfect congruence between both techniques for genotype/subgenotype classification. In a total of 381 patients, HBV genotypes $\mathrm{C}, \mathrm{B}$, and $\mathrm{B} / \mathrm{C}$ mixed genotype were detected in 260 $(68.2 \%), 115(30.2 \%)$, and $6(1.6 \%)$ patients, respectively. The prevalence of HBV genotypes and subgenotypes is summarized in Table 1. All genotype B subgenotypes (115/115) were B2. Genotype C2 (257/260) predominated in genotype C, and the remainder were C1 (3/260). Overall, genotype C2 $(67.5 \%, 257 / 381)$ was the most prevalent subgenotype in this population in Southeast
China, followed by B2 $(30.2 \%, 115 / 381)$. The prevalence of genotype $\mathrm{B}$ in $\mathrm{CHB}$ was higher than in LC or HCC, and the prevalence of genotype $\mathrm{C}$ in $\mathrm{LC}$ or HCC was higher than in $\mathrm{CHB}(\mathrm{P}<0.05)$, but no difference in prevalence of either genotype in LC and HCC was found. The distributions of subgenotypes B2 and $\mathrm{C} 2$ among the three groups were the same as their genotypes (Table 1).

In comparison with the patients infected with $\mathrm{B} 2$, those with $\mathrm{C} 2$ in the $\mathrm{CHB}, \mathrm{LC}$, and $\mathrm{HCC}$ groups had higher serum $\mathrm{HA}$ levels $(\mathrm{P}<0.05)$. In the HCC group, the patients with $\mathrm{C} 2$ were more prone to $\mathrm{HBeAg}$ seropositivity. However, the differences in serum levels of ALT, TBIL, albumin, AFP, and HBV DNA were not significant (Table 2).

In this study, all the $\mathrm{CHB}$ and $\mathrm{HCC}$ patients had complete clinicopathological data. As Table 3 shows, the $\mathrm{CHB}$ patients infected with the $\mathrm{C} 2$ virus staged higher for fibrosis than those with B2 HBV $(\mathrm{P}<0.05)$; no significant difference in inflammation grading was observed. There were no significant differences in tumor number, histological grade, TNM stage, or lymph node metastasis between the patients with B2 or C2 in the HCC group. Interestingly, the patients with $\mathrm{B} 2$ had larger tumors $(\geqslant 5 \mathrm{~cm})$, while those with $\mathrm{C} 2$ were more commonly accompanied by cirrhosis $(\mathrm{P}<0.05$; Table 3$)$.

Mutations with a frequency $>5 \%$ were selected in this study. A total of 13 mutations were detected (Table 4). The frequencies of six mutation patterns in the $\mathrm{CP}$ region (C1653T, G1730C, T1753C, A1762T, G1764A, and G1799C) were higher in LC patients than in CHB patients $(P<0.05)$. The frequencies of 10 mutation patterns (C1653T, G1730C, T1753C, A1762T, G1764A, G1799C C1810T, A1846T, G1862T, and G1896A) were higher in HCC patients than in $\mathrm{CHB}$ patients $(\mathrm{P}<0.05)$. The frequencies of four mutation patterns close to the precore region (C1810T, A1846T, G1862T, and G1896A) were higher in $\mathrm{HCC}$ patients than in $\mathrm{LC}$ patients $(\mathrm{P}<0.05$; Table 4).

To evaluate the associations between the 13 mutations and HBV subgenotype B2/C2 infection, the frequency of each mutation in the patients with $\mathrm{B} 2$ or $\mathrm{C} 2$

Table 1. HBV genotype frequency distributions in 381 patients with chronic HBV infection.

\begin{tabular}{lcccccc}
\hline HBV genotype & CHB $(n=125)$ & $\mathrm{LC}(\mathrm{n}=120)$ & $\mathrm{HCC}(\mathrm{n}=136)$ & $\mathrm{P}^{\mathrm{a}}$ & $\mathrm{P}^{\mathrm{b}}$ & $\mathrm{P}^{\mathrm{c}}$ \\
\hline B & $56(44.8)$ & $25(20.8)$ & $34(25.0)$ & 0.006 & 0.005 & $\mathrm{NS}$ \\
B1 & 0 & 0 & 0 & & & \\
B2 & $56(44.8)$ & $25(20.8)$ & $34(25.0)$ & 0.006 & 0.005 & $\mathrm{NS}$ \\
C & $67(53.6)$ & $92(76.7)$ & $101(74.3)$ & 0.002 & 0.003 & $\mathrm{NS}$ \\
C1 & $1(0.8)$ & $2(1.7)$ & 0 & & \\
C2 & $66(52.8)$ & $90(75.0)$ & $101(74.3)$ & 0.003 & 0.002 & NS \\
B+C mixture & $2(1.6)$ & $3(2.5)$ & $1(0.7)$ & & & \\
\hline
\end{tabular}

Data are reported as number (\%). CHB: chronic hepatitis B; LC: liver cirrhosis; HCC: hepatocellular carcinoma; NS: non-significant. ${ }^{\mathrm{a}} \mathrm{LC}$ vs $\mathrm{CHB} ;{ }^{\mathrm{b}} \mathrm{HCC}$ vs CHB; ${ }^{\mathrm{C}} \mathrm{HCC}$ vs LC. $\mathrm{P}$ values for HBV subgenotype $\mathrm{C} 1$ and the genotype mixture are not shown because of the small sample size. The chi-square test was used for statistical analysis. 
Table 2. Serological and virologic markers for chronically infected patients with HBV subgenotype B2/C2.

\begin{tabular}{|c|c|c|c|}
\hline Markers & $\mathrm{HBV} / \mathrm{B} 2$ & $\mathrm{HBV} / \mathrm{C} 2$ & $\mathrm{P}$ \\
\hline $\mathrm{CHB}$ & $\mathrm{n}=56$ & $\mathrm{n}=66$ & \\
\hline ALT (U/L) & $102.59 \pm 90.25$ & $97.85 \pm 69.26$ & NS \\
\hline TBIL $(\mu \mathrm{M})$ & $48.84 \pm 35.43$ & $50.07 \pm 46.47$ & NS \\
\hline Albumin (g/L) & $37.31 \pm 8.20$ & $39.94 \pm 10.52$ & NS \\
\hline $\mathrm{HA}(\mathrm{ng} / \mathrm{mL})$ & $148.47 \pm 48.63$ & $169.58 \pm 52.04$ & 0.023 \\
\hline $\operatorname{AFP}(\mathrm{ng} / \mathrm{mL})$ & $8.91 \pm 5.67$ & $8.17 \pm 6.39$ & NS \\
\hline $\mathrm{HBeAg}(+)$ & $30(53.6)$ & $38(57.6)$ & NS \\
\hline $\begin{array}{l}\text { HBV DNA } \\
\left(\log _{10} \text { copies } / \mathrm{mL}\right)\end{array}$ & $5.96 \pm 1.28$ & $5.78 \pm 1.34$ & NS \\
\hline LC & $\mathrm{n}=25$ & $\mathrm{n}=90$ & \\
\hline ALT (U/L) & $78.28 \pm 46.57$ & $73.13 \pm 39.46$ & NS \\
\hline TBIL $(\mu \mathrm{M})$ & $74.87 \pm 45.08$ & $76.34 \pm 42.76$ & NS \\
\hline Albumin (g/L) & $30.38 \pm 11.52$ & $29.24 \pm 12.97$ & NS \\
\hline $\mathrm{HA}(\mathrm{ng} / \mathrm{mL})$ & $497.16 \pm 172.90$ & $594.25 \pm 186.12$ & 0.021 \\
\hline $\mathrm{AFP}(\mathrm{ng} / \mathrm{mL})$ & $47.90 \pm 16.34$ & $45.37 \pm 13.54$ & NS \\
\hline $\mathrm{HBeAg}(+)$ & $12(48.0)$ & $53(58.9)$ & NS \\
\hline $\begin{array}{l}\text { HBV DNA } \\
\left(\log _{10} \text { copies } / \mathrm{mL}\right)\end{array}$ & $5.83 \pm 1.16$ & $5.68 \pm 1.43$ & NS \\
\hline $\mathrm{HCC}$ & $n=34$ & $n=101$ & \\
\hline ALT (U/L) & $64.32 \pm 43.27$ & $61.97 \pm 46.38$ & NS \\
\hline TBIL $(\mu \mathrm{M})$ & $29.12 \pm 16.70$ & $26.87 \pm 19.26$ & NS \\
\hline Albumin (g/L) & $33.46 \pm 14.84$ & $34.08 \pm 16.36$ & NS \\
\hline $\mathrm{HA}(\mathrm{ng} / \mathrm{mL})$ & $314.69 \pm 94.85$ & $367.18 \pm 114.67$ & 0.018 \\
\hline $\operatorname{AFP}(\mathrm{ng} / \mathrm{mL})$ & $796.30 \pm 406.67$ & $772.53 \pm 397.48$ & NS \\
\hline $\mathrm{HBeAg}(+)$ & $12(35.3)$ & $56(55.5)$ & 0.038 \\
\hline $\begin{array}{l}\text { HBV DNA } \\
\left(\log _{10} \text { copies } / \mathrm{mL}\right)\end{array}$ & $5.98 \pm 1.06$ & $5.71 \pm 1.37$ & NS \\
\hline
\end{tabular}

Data are reported as means \pm SD or number (\%). CHB: chronic hepatitis B; LC: liver cirrhosis; HCC: hepatocellular carcinoma; ALT: alanine aminotransferase; TBIL: total bilirubin; HA: hyaluronic acid; AFP: $\alpha$-fetoprotein; HBeAg: HBV e-antigen; NS: nonsignificant. The Student $t$-test, the Mann-Whitney U-test and the chi-square test were used for statistical analysis.

subgenotype was compared. Seven mutation patterns (C1653T, G1719T, G1730C, T1753C, A1762T, G1764A, and $\mathrm{G} 1799 \mathrm{C}$ ) in the $\mathrm{CP}$ region were more prevalent in the patients with the $\mathrm{C} 2$ than with the $\mathrm{B} 2$ subgenotype $(\mathrm{P}<0.05)$. Four mutation patterns (C1810T, A1846T, $\mathrm{G} 1862 \mathrm{~T}$, and $\mathrm{G} 1896 \mathrm{~A}$ ) close to the precore region were more prevalent in the patients with the $\mathrm{B} 2$ than with the $\mathrm{C} 2$ subgenotype $(\mathrm{P}<0.001$; Table 5$)$.

Table 6 shows seven combined mutation patterns ( $>5 \%$ frequency) that were all double or triple combined mutations. The frequencies of all combined mutations in LC or HCC were higher than in $\mathrm{CHB}(\mathrm{P}<0.05)$, but no difference was found between LC and HCC. The A1762T/ G1764A double mutation was highly prevalent, occurring in $36.9 \%$ of $\mathrm{CHB}$ patients, $63.6 \%$ of LC patients, and $60.0 \%$ of HCC patients. Each of the combined mutations detected in this study included the A1762T and/or the $\mathrm{G} 1764 \mathrm{~A}$ variant.
Table 3. Clinicopathological characteristics in $\mathrm{CHB}$ and $\mathrm{HCC}$ patients with HBV subgenotype B2/C2 infection.

\begin{tabular}{|c|c|c|c|}
\hline Characteristics & HBV/B2 & $\mathrm{HBV} / \mathrm{C} 2$ & $\mathrm{P}$ \\
\hline $\mathrm{CHB}$ & $\mathrm{n}=56$ & $\mathrm{n}=66$ & \\
\hline \multicolumn{4}{|l|}{ Grade } \\
\hline $1-2$ & $31(55.4)$ & $30(45.5)$ & NS \\
\hline $3-4$ & $25(44.6)$ & $36(54.5)$ & \\
\hline \multicolumn{4}{|l|}{ Stage } \\
\hline $0-2$ & $43(76.8)$ & $37(56.1)$ & 0.025 \\
\hline $3-4$ & $14(25.0)$ & $29(43.9)$ & \\
\hline $\mathrm{HCC}$ & $\mathrm{n}=34$ & $n=101$ & \\
\hline \multicolumn{4}{|c|}{ Tumor number } \\
\hline Single & $22(64.7)$ & $74(73.3)$ & NS \\
\hline Multiple & $12(35.3)$ & $27(26.7)$ & \\
\hline \multicolumn{4}{|l|}{ Tumor size } \\
\hline$<5 \mathrm{~cm}$ & $11(32.4)$ & $53(52.5)$ & 0.037 \\
\hline$\geqslant 5 \mathrm{~cm}$ & $23(67.6)$ & $47(46.5)$ & \\
\hline \multicolumn{4}{|c|}{ Histological grade } \\
\hline$I+I I$ & $24(70.6)$ & $68(67.3)$ & NS \\
\hline III+IV & $10(29.4)$ & $33(32.7)$ & \\
\hline \multicolumn{4}{|l|}{ TNM stage } \\
\hline$I+I I$ & $27(79.4)$ & $86(85.1)$ & NS \\
\hline III+IV & 7 (20.6) & $15(14.9)$ & \\
\hline \multicolumn{4}{|c|}{ Lymph node metastasis } \\
\hline Present & $12(35.3)$ & $27(26.7)$ & NS \\
\hline Absent & $22(64.7)$ & $74(73.3)$ & \\
\hline \multicolumn{4}{|l|}{ Cirrhosis } \\
\hline Present & $8(23.5)$ & $43(42.6)$ & 0.048 \\
\hline Absent & $26(76.5)$ & $58(57.4)$ & \\
\hline
\end{tabular}

Data are reported as number (\%). The pathological examination for liver biopsy in chronic hepatitis B (CHB) patients was according to Scheuer's classification; the histological assay was determined by referencing the standard of Edmondson grade; tumor stage was classified according to the TNM criteria of the International Union Against Cancer. HBV: hepatitis B virus; HCC: hepatocellular carcinoma; NS: non-significant. The chi-square test was used for statistical analysis.

To analyze the independent risk factors for the progression of chronic liver disease, the multiple variants were evaluated by multivariate regression, including $\mathrm{HBeAg}$ status, HBV subgenotype, and the presence of C1653T, G1730C, T1753C, A1762T, G1764A, G1799C, C1810T, A1846T, G1862T, or G1896A mutations (Table 7). When $\mathrm{CHB}$ patients were the control, HBV subgenotype $\mathrm{C} 2$ infection and $\mathrm{C} 2$-associated mutation patterns (C1653T, T1753C, A1762T, and G1764A) in the $\mathrm{CP}$ region were independent risk factors for $\mathrm{LC}$ or $\mathrm{C} 2$ infection, and eight mutation patterns (C1653T, T1753C, A1762T, G1764A, C1810T, A1846T, G1862T, and $\mathrm{G} 1896 \mathrm{~A})$ were independent risk factors for HCC. When LC patients were the control, HBV subgenotype B2associated mutation patterns (C1810T, A1846T, G1862T, and $\mathrm{G} 1896 \mathrm{~A}$ ) close to the precore region were independent risk factors for HCC. 
Table 4. Thirteen mutations in the enhll/BCP/precore regions of HBV in chronically infected patients.

\begin{tabular}{|c|c|c|c|c|c|c|c|}
\hline Substitution & $\mathrm{ASC}_{\mathrm{S}}(\mathrm{n}=844)$ & $\mathrm{CHB}(n=125)$ & $\operatorname{LC}(n=120)$ & $\operatorname{HCC}(n=136)$ & $\mathrm{P}^{\mathrm{a}}$ & $\mathrm{P}^{\mathrm{b}}$ & $P^{c}$ \\
\hline C1653T & $68(8.1)$ & $8(6.4)$ & $22(18.3)$ & $32(23.5)$ & 0.004 & $<0.001$ & NS \\
\hline T1674C & $64(7.6)$ & $25(20.0)$ & 34 (28.3) & $36(26.5)$ & NS & NS & NS \\
\hline G1719T & $150(17.8)$ & $65(52.0)$ & $67(55.8)$ & 75 (55.1) & NS & NS & NS \\
\hline G1730C & $214(25.4)$ & $73(58.4)$ & $88(73.3)$ & 97 (71.3) & 0.014 & 0.029 & NS \\
\hline T1753C & $49(5.8)$ & $8(6.4)$ & $25(20.8)$ & $30(22.1)$ & 0.001 & $<0.001$ & NS \\
\hline $\mathrm{A} 1762 \mathrm{~T}$ & $145(17.2)$ & $51(40.8)$ & $70(58.3)$ & $81(59.6)$ & 0.006 & 0.002 & NS \\
\hline G1764A & $186(22.0)$ & $55(44.0)$ & $80(66.7)$ & $86(63.2)$ & $<0.001$ & 0.002 & NS \\
\hline G1799C & $183(21.7)$ & $70(56.0)$ & $94(78.3)$ & $101(74.3)$ & $<0.001$ & 0.002 & NS \\
\hline C1810T & 0 & $2(1.6)$ & 7 (5.8) & $26(19.1)$ & NS & $<0.001$ & 0.002 \\
\hline A1846T & 67 (7.9) & $31(24.8)$ & $34(28.3)$ & 55 (40.4) & NS & $<0.001$ & $<0.001$ \\
\hline G1862T & 0 & 7 (5.6) & 7 (5.8) & $30(22.1)$ & NS & 0.002 & 0.010 \\
\hline G1896A & $150(17.8)$ & $51(40.8)$ & $52(43.3)$ & $81(59.6)$ & NS & 0.002 & 0.010 \\
\hline G1899A & 0 & $22(17.6)$ & $25(20.8)$ & $17(12.5)$ & NS & NS & NS \\
\hline
\end{tabular}

Data are reported as number (\%). Hepatitis B virus (HBV) mutation data for asymptomatic HBsAg carrier (ASC) state were organized as in the study by Yin et al. (27). A nucleotide with the highest frequency at each site in the enhll/BCP/precore regions of HBV from ASCs was defined as the wild-type nucleotide. Nucleotide substitutions at each site were defined as mutations. Enhll: enhancer II region of HBV; BCP: basal core promoter region of HBV; CHB: chronic hepatitis B; LC: liver cirrhosis; HCC: hepatocellular carcinoma; NS: non-significant. ${ }^{a} \mathrm{LC}$ vs $\mathrm{CHB} ;{ }^{\mathrm{b}} \mathrm{HCC}$ vs $\mathrm{CHB}$; ${ }^{\mathrm{C}} \mathrm{HCC}$ vs LC. The chi-square test or the Fisher exact test was used for statistical analysis.

\section{Discussion}

It is generally accepted that HBV genotypes vary in geographic distribution and show a distinct association with the clinical progression of liver disease $(6-10,14,16)$. A cross-sectional study of 270 Taiwanese patients with chronic HBV infection demonstrated that HBV genotype $\mathrm{C}$ was associated with more severe liver disease and that

Table 5. Determination of subgenotype-associated mutations in the enhll/BCP/precore regions of HBV.

\begin{tabular}{lccc}
\hline Substitution & $\begin{array}{c}\text { Subgenotype B2 } \\
(\mathrm{n}=115)\end{array}$ & $\begin{array}{c}\text { Subgenotype C2 } \\
(\mathrm{n}=257)\end{array}$ & $\mathrm{P}$ \\
\hline C1653T & $10(8.7)$ & $51(19.8)$ & 0.006 \\
T1674C & $8(7.0)$ & $32(12.5)$ & $\mathrm{NS}$ \\
G1719T & $17(14.8)$ & $151(58.8)$ & $<0.001$ \\
G1730C & $25(21.7)$ & $233(90.7)$ & $<0.001$ \\
T1753C & $6(5.2)$ & $57(22.2)$ & $<0.001$ \\
A1762T & $24(20.9)$ & $173(67.3)$ & $<0.001$ \\
G1764A & $23(20.0)$ & $178(69.3)$ & $<0.001$ \\
G1799C & $6(5.2)$ & $246(95.7)$ & $<0.001$ \\
C1810T & $24(20.9)$ & $5(1.9)$ & $<0.001$ \\
A1846T & $57(49.6)$ & $38(14.8)$ & $<0.001$ \\
G1862T & $24(20.9)$ & $25(9.7)$ & $<0.001$ \\
G1896A & $81(70.4)$ & $84(32.7)$ & $<0.001$ \\
G1899A & $25(21.7)$ & $43(16.7)$ & NS \\
\hline
\end{tabular}

Data are reported as number (\%). enhll: enhancer II region of hepatitis B virus (HBV); BCP: basal core promoter region of HBV; NS: non-significant. The chi-square test was used for statistical analysis. genotype B may be associated with the development of $\mathrm{HCC}$ in young Taiwanese (28). A survey from North China reported that HBV genotypes B (14.6\%), C (84.2\%), and D $(1.2 \%)$ were detected in 1301 chronically infected patients. Among them, subgenotypes C2 (77.2\%) and B2 $(17.8 \%)$ were identified. It was suggested that genotype $C$ infection was likely to be associated with a longer disease duration and more severe impairment of liver function than genotype B infection (29). Another report from Southern China revealed that genotype B accounted for more than $50 \%$ of cases and that subgenotypes $\mathrm{C} 1$ (33.6\%), B2 (51.2\%), and C2 (15.2\%) were endemic (16). These data revealed that the prevalence of HBV genotype $\mathrm{C}$ and subgenotype C2 decreased, whereas the prevalence of genotype $B$, and subgenotypes $B 2$ and $C 1$ increased from north to south in China.

In our study, HBV genotype C (68.2\%) predominated, and genotype $\mathrm{B}(30.2 \%)$ was the second most common in chronically infected patients. Of these, C2 (67.5\%) was the most prevalent subgenotype followed by B2 (30.2\%), and $\mathrm{C} 1$. The proportion of HBV subgenotype $\mathrm{C} 2$ increased from $\mathrm{CHB}$ to $\mathrm{HCC}$ and $\mathrm{LC}$, while that of $\mathrm{B} 2$ decreased. Subgenotype C2 was associated with LC and $\mathrm{HCC}$, whereas B2 was associated with $\mathrm{CHB}$ in univariate analyses.

In each of the three patient groups, serum HA levels were significantly higher in participants with subgenotype C2 than in those with subgenotype B2, which indicated that patients with $\mathrm{C} 2$ were more likely to progress to severe liver fibrosis and cirrhosis than patients with B2. Additionally, HCC group patients with subgenotype C2 had a higher $\mathrm{HBeAg}$ seropositivity rate than those with 
Table 6. Combined mutations in the enhll/BCP/precore regions of HBV.

\begin{tabular}{|c|c|c|c|c|c|c|}
\hline Combined mutation patterns & $\mathrm{CHB}(n=122)$ & LC $(n=115)$ & $\operatorname{HCC}(n=135)$ & $\mathrm{P}^{\mathrm{a}}$ & $\mathrm{P}^{\mathrm{b}}$ & $\mathrm{P}^{\mathrm{C}}$ \\
\hline $\mathrm{C} 1653 \mathrm{~T}+\mathrm{A} 1762 \mathrm{~T}$ & $2(1.6)$ & $11(9.6)$ & $16(11.9)$ & 0.003 & $<0.001$ & NS \\
\hline $\mathrm{C} 1653 \mathrm{~T}+\mathrm{G} 1764 \mathrm{~A}$ & $3(2.5)$ & $14(12.2)$ & $17(12.6)$ & 0.002 & $<0.001$ & NS \\
\hline $\mathrm{A} 1762 \mathrm{~T}+\mathrm{G} 1764 \mathrm{~A}$ & $45(36.9)$ & $73(63.5)$ & $81(60.0)$ & $<0.001$ & $<0.001$ & NS \\
\hline $\mathrm{C} 1653 \mathrm{~T}+\mathrm{A} 1762 \mathrm{~T}+\mathrm{G} 1764 \mathrm{~A}$ & $2(1.6)$ & $10(8.7)$ & $16(11.9)$ & 0.004 & $<0.001$ & NS \\
\hline $\mathrm{T} 1753 \mathrm{C}+\mathrm{A} 1762 \mathrm{~T}+\mathrm{G} 1764 \mathrm{~A}$ & $8(6.6)$ & $27(23.5)$ & $28(20.7)$ & $<0.001$ & $<0.001$ & NS \\
\hline $\mathrm{A} 1762 \mathrm{~T}+1764 \mathrm{~A}+\mathrm{G} 1799 \mathrm{C}$ & $28(23.0)$ & $57(49.6)$ & $65(48.1)$ & $<0.001$ & $<0.001$ & NS \\
\hline $\mathrm{A} 1762 \mathrm{~T}+1764 \mathrm{~A}+\mathrm{G} 1896 \mathrm{~A}$ & $8(6.6)$ & $17(14.8)$ & $30(22.2)$ & 0.039 & $<0.001$ & NS \\
\hline
\end{tabular}

Data are reported as number (\%). BCP: basal core promoter; HBV: hepatitis B virus; CHB: chronic hepatitis B; LC: liver cirrhosis; HCC: hepatocellular carcinoma; NS: non-significant. ${ }^{\mathrm{a}} \mathrm{LC}$ vs $\mathrm{CHB} ;{ }^{\mathrm{b}} \mathrm{HCC}$ vs $\mathrm{CHB} ;{ }^{\mathrm{c}} \mathrm{HCC}$ vs LC. The chi-square test or the Fisher exact test was used for statistical analysis.

subgenotype B2, which was not observed in $\mathrm{CHB}$ and LC patients. This result suggests that the difference in capacity for $\mathrm{HBeAg}$ seroconversion between patients with subgenotype B2 or C2 did not appear until chronic liver disease progressed to HCC.

Previous studies suggested that the HBV genotype may affect the clinical behavior of $\operatorname{HCC}(30,31)$. However, the influence of HBV subgenotype on the clinicopathological features of liver disease in Southeast China is not well understood. In this study, we found that $\mathrm{CHB}$ patients infected with subgenotype $\mathrm{C} 2$ had a higher fibrosis staging than those with the B2 subgenotype, according to Scheuer's classification. This result was supported by the serological assay results for HA levels. Interestingly, HCC patients with B2 accounted for a higher proportion of tumors $\geqslant 5 \mathrm{~cm}$, whereas those with the C2 subgenotype were more likely to progress to cirrhosis. This finding has rarely been reported in the published literature, and extensive supporting clinical data are still needed.

HBV mutation data for ASCs from the study by Yin et al. (27) are applicable to our data because, in that study, the subjects were from Southeast China, the sample size was large enough, frequencies of HBV genotypes/ subgenotypes in the total sample were similar to our results, and mutational analysis was achieved by sequencing. In our study, we detected 13 mutations in the enhll/ $\mathrm{BCP} /$ precore regions of $\mathrm{HBV}$. Univariate analyses showed that 6 mutation patterns (C1653T, G1730C, T1753C, A1762T, G1764A, and G1799C) located in the $\mathrm{CP}$ region were associated with $\mathrm{LC}$ compared with $\mathrm{CHB}$ $(P<0.05)$. Ten mutation patterns (C1653T, G1730C, T1753C, A1762T, G1764A, G1799C, C1810T, A1846T, G1862T, and G1896A) were associated with HCC compared with $\mathrm{CHB}(\mathrm{P}<0.05)$, and 4 mutation patterns (C1810T, A1846T, G1862T, and G1896A) located close to the precore region were associated with $\mathrm{HCC}$ compared with LC $(\mathrm{P}<0.05)$.

Seven of 13 mutation patterns (C1653T, G1719T, G1730C, T1753C, A1762T, G1764A, and G1799C) in the
$\mathrm{CP}$ region were associated with $\mathrm{C} 2$ infection, and 4 mutation patterns (C1810T, A1846T, G1862T, and $\mathrm{G} 1896 \mathrm{~A}$ ) close to the precore region were associated with B2 infection.

The prevalence and clinical implication of the combined mutations in the enhll/BCP/precore regions have been published $(21,32)$. Seven combined mutations detected by this study were associated with the development of chronic HBV infection. Each combined mutation containing A1762T and/or G1764A occurred in the early stage of advanced liver disease, which means that the A1762T and/or G1764A mutation may stimulate the occurrence of the other mutations in the enhll/BCP/ precore regions.

Multivariate analysis revealed that HBV subgenotype C2 infection and C2-associated mutation patterns (C1653T, T1753C, A1762T, and G1764A) contributed to the development of $\mathrm{LC}$ from $\mathrm{CHB}$, and that B2-associated mutation patterns (C1810T, A1846T, G1862T, and G1896A) contributed to the development of HCC from LC. We speculate that HBV subgenotype $\mathrm{C} 2$ and $\mathrm{C} 2$-associated mutations may be related to the progression from liver necroinflammation to cirrhosis, whereas B2-associated mutations may be involved in hepatocarcinogenesis.

The underlying mechanisms of the mutations in the enhll/BCP/precore regions of $\mathrm{HBV}$ and their impact on the occurrence of LC and HCC are unclear. The C1653T mutation occurs at the center of the immunodominant antigenic domain and may be involved in inflammatory processes (33). The T1753C mutation enhances viral replication, leading to persistent infection (34). The A1762T and G1764A mutations are associated with diminished HBeAg production at the transcriptional level, enhanced host immune response, and viral replication (34). The C1810T and G1862T mutations affect the expression of $\mathrm{HBeAg}$ at the translational and posttranslational levels, respectively (35). The G1896A mutation produces a stop codon for $\mathrm{HBeAg}$ expression (36), while the role of the $\mathrm{A} 1846 \mathrm{~T}$ mutation in the regulation of $\mathrm{HBeAg}$ expression requires further study. In addition, the 
Table 7. Multivariate analysis of independent risk factors for LC and HCC, respectively.

\begin{tabular}{|c|c|c|c|c|c|c|}
\hline \multirow[t]{2}{*}{ Factor } & \multicolumn{2}{|c|}{ LC (CHB as control) } & \multicolumn{2}{|c|}{$\mathrm{HCC}(\mathrm{CHB}$ as control) } & \multicolumn{2}{|c|}{$\mathrm{HCC}$ (LC as control) } \\
\hline & OR $(95 \% \mathrm{Cl})$ & $\mathrm{P}$ & OR $(95 \% \mathrm{Cl})$ & $\mathrm{P}$ & OR $(95 \% \mathrm{Cl})$ & $\mathrm{P}$ \\
\hline \multicolumn{7}{|c|}{ HBV subgenotype } \\
\hline B2 & 1 & & 1 & & 1 & \\
\hline $\mathrm{C} 2$ & $2.368(1.082-4.157)$ & 0.002 & $2.401(1.136-4.308)$ & 0.001 & $0.807(0.430-1.514)$ & NS \\
\hline \multicolumn{7}{|l|}{$\mathrm{HBeAg}$} \\
\hline Negative & 1 & & 1 & & 1 & \\
\hline Positive & $0.969(0.561-1.673)$ & NS & $0.925(0.493-1.617)$ & NS & $0.964(0.526-1.705)$ & NS \\
\hline \multicolumn{7}{|l|}{ C1653T } \\
\hline C & 1 & & 1 & & 1 & \\
\hline $\mathrm{T}$ & $2.350(1.071-5.212)$ & 0.020 & $2.974(1.466-6.094)$ & 0.001 & $1.371(0.715-2.636)$ & NS \\
\hline \multicolumn{7}{|l|}{ G1730C } \\
\hline G & 1 & & 1 & & 1 & \\
\hline C & $1.609(0.932-2.812)$ & NS & $1.339(0.794-2.262)$ & NS & $0.904(0.503-1.624)$ & NS \\
\hline \multicolumn{7}{|l|}{ T1753C } \\
\hline $\mathrm{T}$ & 1 & & 1 & & 1 & \\
\hline C & $2.753(1.273-6.021)$ & 0.005 & $1.985(0.992-4.005)$ & 0.036 & $1.075(0.567-2.043)$ & NS \\
\hline \multicolumn{7}{|l|}{$\mathrm{A} 1762 \mathrm{~T}$} \\
\hline A & 1 & & 1 & & 1 & \\
\hline $\mathrm{T}$ & $1.713(1.024-2.870)$ & 0.029 & $1.669(1.016-2.723)$ & 0.026 & $1.052(0.619-1.787)$ & NS \\
\hline \multicolumn{7}{|l|}{ G1764A } \\
\hline G & 1 & & 1 & & 1 & \\
\hline A & $1.668(0.997-2.792)$ & 0.038 & $1.764(1.077-2.891)$ & 0.017 & $0.860(0.497-1.487)$ & NS \\
\hline \multicolumn{7}{|l|}{ G1799C } \\
\hline G & 1 & & 1 & & 1 & \\
\hline C & $0.843(0.516-1.420)$ & NS & $1.597(0.938-2.725)$ & NS & $0.898(0.629-1.582)$ & NS \\
\hline \multicolumn{7}{|l|}{$\mathrm{C} 1810 \mathrm{~T}$} \\
\hline C & 1 & & 1 & & 1 & \\
\hline $\mathrm{T}$ & $0.614(0.442-1.416)$ & NS & $15.012(3.395-92.783)$ & $<0.001$ & $2.935(1.275-7.086)$ & 0.005 \\
\hline \multicolumn{7}{|l|}{ A1846T } \\
\hline A & 1 & & 1 & & 1 & \\
\hline $\mathrm{T}$ & $1.457(0.832-2.563)$ & NS & $2.175(1.261-3.764)$ & 0.003 & $1.752(0.991-3.106)$ & 0.038 \\
\hline \multicolumn{7}{|l|}{ G1862T } \\
\hline G & 1 & & 1 & & 1 & \\
\hline $\mathrm{T}$ & $1.588(0.568-4.567)$ & NS & $4.797(1.943-2.360)$ & $<0.001$ & $4.569(1.818-1.965)$ & $<0.001$ \\
\hline \multicolumn{7}{|l|}{ G1896A } \\
\hline G & 1 & & 1 & & 1 & \\
\hline$A$ & $1.408(0.836-2.375)$ & NS & $2.217(1.256-3.165)$ & 0.002 & $1.926(1.136-3.270)$ & 0.008 \\
\hline
\end{tabular}

CHB: chronic hepatitis B; LC: liver cirrhosis; HCC: hepatocellular carcinoma; HBV: hepatitis B virus; HbeAg: HBV e-antigen; Cl: confidence interval; OR: odds ratio; NS: non-significant. Multiple logistic regressions were used for statistical analysis.

C1653T, T1753C, A1762T, and G1764A mutations lead to H94Y, I127T, K130M, and V131I amino acid substitutions in $\mathrm{HBx}$. These changes, located in regions $\mathrm{D}(\sim 85-119$ amino acids) and $E(\sim 120-140$ amino acids) of the $\mathrm{HBx}$ functional region, could abrogate the transactivation of $\mathrm{HBx}$, which is associated with hepatocarcinogenesis (37). The C1653T, T1753C, A1762T, and G1764A mutations may play critical roles in persistent viral infections and inflammatory processes, and therefore may be responsible for severe liver fibrosis. The C1810T, A1846T, G1862T, and G1896A mutations most likely result in crude expression of $\mathrm{HBeAg}$ and accumulation of the $\mathrm{HBeAg}$ precursor in the endoplasmic reticulum/Golgi apparatus of the cell (38). This accumulation could affect various cellular pathways that contribute to the development of HCC.

In conclusion, our study systemically investigated the relationship of HBV genotypes/subgenotypes and enhll/ $\mathrm{BCP} /$ precore mutations to the progression of chronic HBV infection. We found that the HBV subgenotypes C2 and B2 predominated in chronically infected patients in 
Southeast China. Our results showed that HBV subgenotype C2 and C2-associated mutation patterns (C1653T, T1753C, A1762T, and G1764A) were independent risk factors for $\mathrm{LC}$ when $\mathrm{CHB}$ was the control and that B2associated mutation patterns (C1810T, A1846T, G1862T, and $\mathrm{G} 1896 \mathrm{~A}$ ) were independent risk factors for HCC when LC was the control.

\section{References}

1. Lau GK. Hepatitis B infection in China. Clin Liver Dis 2001; 5: 361-379, doi: 10.1016/S1089-3261(05)70170-7.

2. Kurbanov F, Tanaka Y, Mizokami M. Geographical and genetic diversity of the human hepatitis $\mathrm{B}$ virus. Hepatol Res 2010; 40: 14-30, doi: 10.1111/j.1872-034X.2009.00601.x.

3. Devesa M, Pujol FH. Hepatitis B virus genetic diversity in Latin America. Virus Res 2007; 127: 177-184, doi: 10.1016/ j.virusres.2007.01.004

4. Schaefer S. Hepatitis B virus taxonomy and hepatitis B virus genotypes. World J Gastroenterol 2007; 13: 14-21.

5. Lin $\mathrm{CL}$, Kao JH. The clinical implications of hepatitis B virus genotype: Recent advances. J Gastroenterol Hepatol 2011; 26 (Suppl 1): 123-130, doi: 10.1111/j.1440-1746.2010.06541.x.

6. Fung SK, Lok AS. Hepatitis B virus genotypes: do they play a role in the outcome of HBV infection? Hepatology 2004; 40: 790-792.

7. Livingston SE, Simonetti JP, Bulkow LR, Homan CE, Snowball MM, Cagle HH, et al. Clearance of hepatitis B e antigen in patients with chronic hepatitis $B$ and genotypes $A$, B, C, D, and F. Gastroenterology 2007; 133: 1452-1457, doi: 10.1053/j.gastro.2007.08.010.

8. Buti M, Elefsiniotis I, Jardi R, Vargas V, Rodriguez-Frias F, Schapper M, et al. Viral genotype and baseline load predict the response to adefovir treatment in lamivudine-resistant chronic hepatitis B patients. J Hepatol 2007; 47: 366-372, doi: 10.1016/j.jhep.2007.04.011.

9. Chou YC, Yu MW, Wu CF, Yang SY, Lin CL, Liu CJ, et al. Temporal relationship between hepatitis B virus enhancer II/ basal core promoter sequence variation and risk of hepatocellular carcinoma. Gut 2008; 57: 91-97, doi: 10.1136/gut.2006.114066.

10. Imamura T, Yokosuka O, Kurihara T, Kanda T, Fukai $\mathrm{K}$ Imazeki $F$, et al. Distribution of hepatitis B viral genotypes and mutations in the core promoter and precore regions in acute forms of liver disease in patients from Chiba, Japan. Gut 2003; 52: 1630-1637, doi: 10.1136/gut.52.11.1630.

11. Ngui $S L$, Hallet R, Teo CG. Natural and iatrogenic variation in hepatitis B virus. Rev Med Virol 1999; 9: 183-209, doi: 10.1002/(SICI)1099-1654(199907/09)9:3<183::AIDRMV248>3.0.CO;2-P

12. Kao JH, Chen PJ, Lai MY, Chen DS. Basal core promoter mutations of hepatitis $B$ virus increase the risk of hepatocellular carcinoma in hepatitis B carriers. Gastroenterology 2003; 124: 327-334, doi: 10.1053/gast.2003.50053.

13. Zhu R, Zhang HP, $\mathrm{Yu} \mathrm{H}$, Li H, Ling $Y Q, H u X Q$, et al. Hepatitis $B$ virus mutations associated with in situ expression of hepatitis B core antigen, viral load and prognosis in chronic hepatitis B patients. Pathol Res Pract 2008; 204: 731-742, doi: 10.1016/j.prp.2008.05.001

\section{Acknowledgments}

We thank Qiao-Feng Tu and Wen-Juan Tong for excellent technical assistance and Xiang Fang for serum specimen processing and acquisition. Research supported by the Hangzhou Board of Health (\#2009Z001), Zhejiang Province, China.

14. Liao Y, Hu X, Chen J, Cai B, Tang J, Ying B, et al. Precore mutation of hepatitis $B$ virus may contribute to hepatocellular carcinoma risk: evidence from an updated metaanalysis. PLoS One 2012; 7: e38394, doi: 10.1371/journal. pone.0038394.

15. Kao JH, Chen PJ, Lai MY, Chen DS. Genotypes and clinical phenotypes of hepatitis B virus in patients with chronic hepatitis B virus infection. J Clin Microbiol 2002; 40: 12071209, doi: 10.1128/JCM.40.4.1207-1209.2002.

16. Wang Z, Tanaka Y, Huang Y, Kurbanov F, Chen J, Zeng G, et al. Clinical and virological characteristics of hepatitis $B$ virus subgenotypes $\mathrm{Ba}, \mathrm{C} 1$, and $\mathrm{C} 2$ in China. J Clin Microbiol 2007; 45: 1491-1496, doi: 10.1128/JCM.02157-06.

17. Lok AS, Akarca U, Greene S. Mutations in the pre-core region of hepatitis $B$ virus serve to enhance the stability of the secondary structure of the pre-genome encapsidation signal. Proc Natl Acad Sci U S A 1994; 91: 4077-4081, doi: 10.1073/pnas.91.9.4077.

18. Yuen MF, Tanaka Y, Shinkai N, Poon RT, But DY, Fong DY, et al. Risk for hepatocellular carcinoma with respect to hepatitis $B$ virus genotypes $B / C$, specific mutations of enhancer II/core promoter/precore regions and HBV DNA levels. Gut 2008; 57: 98-102, doi: 10.1136/gut.2007.119859.

19. Yang HI, Yeh SH, Chen PJ, lloeje UH, Jen CL, Su J, et al. Associations between hepatitis B virus genotype and mutants and the risk of hepatocellular carcinoma. J Natl Cancer Inst 2008; 100: 1134-1143, doi: 10.1093/jnci/djn243.

20. Tseng TC, Liu CJ, Chen PJ, Lai MY, Lin CL, Kao JH, et al. Subgenotypes of hepatitis B virus genotype C do not correlate with disease progression of chronic hepatitis $B$ in Taiwan. Liver Int 2007; 27: 983-988, doi: 10.1111/j.14783231.2007.01546.X.

21. Guo X, Jin Y, Qian G, Tu H. Sequential accumulation of the mutations in core promoter of hepatitis $B$ virus is associated with the development of hepatocellular carcinoma in Qidong, China. J Hepatol 2008; 49: 718-725, doi: 10.1016/ j.jhep.2008.06.026.

22. Truong BX, Yano Y, Seo Y, Phuong TM, Tanaka Y, Kato H, et al. Variations in the core promoter/pre-core region in HBV genotype $\mathrm{C}$ in Japanese and Northern Vietnamese patients. J Med Virol 2007; 79: 1293-1304, doi: 10.1002/jmv.20934.

23. Scheuer PJ. Classification of chronic viral hepatitis: a need for reassessment. J Hepatol 1991; 13: 372-374, doi: 10.1016/0168-8278(91)90084-O.

24. Tanaka Y, Orito E, Yuen MF, Mukaide M, Sugauchi F, Ito K, et al. Two subtypes (subgenotypes) of hepatitis B virus genotype C: A novel subtyping assay based on restriction fragment length polymorphism. Hepatol Res 2005; 33 216-224. 
25. Sugauchi $F$, Kumada $H$, Sakugawa $H$, Komatsu M, Niitsuma $\mathrm{H}$, Watanabe $\mathrm{H}$, et al. Two subtypes of genotype $\mathrm{B}$ ( $\mathrm{Ba}$ and Bj) of hepatitis B virus in Japan. Clin Infect Dis 2004; 38: 1222-1228, doi: $10.1086 / 382885$

26. Liu Y, Zhong Y, Zou Z, Xu Z, Li B, Ren X, et al. Features and clinical implications of hepatitis $B$ virus genotypes and mutations in basal core promoter/precore region in 507 Chinese patients with acute and chronic hepatitis B. J Clin Virol 2010; 47: 243-247, doi: 10.1016/j.jcv.2009.12.013.

27. Yin J, Xie J, Liu S, Zhang H, Han L, Lu W, et al. Association between the various mutations in viral core promoter region to different stages of hepatitis $\mathrm{B}$, ranging of asymptomatic carrier state to hepatocellular carcinoma. Am J Gastroenterol 2011; 106: 81-92, doi: 10.1038/ajg.2010.399.

28. Kao JH, Chen PJ, Lai MY, Chen DS. Hepatitis B genotypes correlate with clinical outcomes in patients with chronic hepatitis B. Gastroenterology 2000; 118: 554-559, doi: 10.1016/S0016-5085(00)70261-7.

29. Li XD, Wang L, Liu $Y, X u Z H$, Dai JZ, Li L, et al. Characterization of hepatitis $B$ virus genotypes/subgenotypes in 1,301 patients with chronic hepatitis B in North China. Chin Med J 2011; 124: 4178-4183.

30. Chen JD, Liu CJ, Lee PH, Chen PJ, Lai MY, Kao JH, et al. Hepatitis B genotypes correlate with tumor recurrence after curative resection of hepatocellular carcinoma. Clin Gastroenterol Hepatol 2004; 2: 64-71, doi: 10.1016/ S1542-3565(03)00293-3.

31. Lin CL, Chen JD, Liu CJ, Lee PH, Chen PJ, Lai MY, et al. Clinicopathological differences between hepatitis $B$ viral genotype B- and C-related resectable hepatocellular carcinoma. J Viral Hepat 2007; 14: 64-69, doi: 10.1111/ j.1365-2893.2006.00776.x.

32. Liu S, Zhang H, Gu C, Yin J, He Y, Xie J, et al. Associations between hepatitis $B$ virus mutations and the risk of hepatocellular carcinoma: a meta-analysis. J Natl Cancer Inst 2009; 101: 1066-1082, doi: 10.1093/jnci/djp180.

33. Stemler M, Weimer T, Tu ZX, Wan DF, Levrero M, Jung C, et al. Mapping of B-cell epitopes of the human hepatitis $\mathrm{B}$ virus X protein. J Virol 1990; 64: 2802-2809.

34. Kitab B, Essaid EI FA, Afifi R, Trepo C, Benazzouz M, Essamri W, et al. Variability in the precore and core promoter regions of HBV strains in Morocco: characterization and impact on liver disease progression. PLOS One 2012; 7: e42891, doi: 10.1371/journal.pone.0042891.

35. Makondo E, Bell TG, Kramvis A. Genotyping and molecular characterization of hepatitis $B$ virus from human immunodeficiency virus-infected individuals in southern Africa. PLoS One 2012; 7: e46345, doi: 10.1371/journal.pone.0046345.

36. Laras A, Koskinas J, Avgidis K, Hadziyannis SJ. Incidence and clinical significance of hepatitis $\mathrm{B}$ virus precore gene translation initiation mutations in e antigen-negative patients. J Viral Hepat 1998; 5: 241-248, doi: 10.1046/ j.1365-2893.1998.00109.x.

37. Kumar V, Jayasuryan N, Kumar R. A truncated mutant (residues 58-140) of the hepatitis $B$ virus $X$ protein retains transactivation function. Proc Natl Acad Sci U S A 1996; 93: 5647-5652, doi: 10.1073/pnas.93.11.5647.

38. Chen $C Y$, Crowther $C$, Kew MC, Kramvis A. A valine to phenylalanine mutation in the precore region of hepatitis $B$ virus causes intracellular retention and impaired secretion of HBe-antigen. Hepatol Res 2008; 38: 580-592, doi: 10.1111/ j.1872-034X.2007.00315.x. 